\title{
The synergy and mode of action of quercetin plus amoxicillin against amoxicillin-resistant Staphylococcus epidermidis
}

\author{
Supatcharee Siriwong ${ }^{1}$, Yothin Teethaisong ${ }^{1}$, Kanjana Thumanu², Benjawan Dunkhunthod ${ }^{1}$ \\ and Griangsak Eumkeb ${ }^{1 *}$
}

\begin{abstract}
Background: Staphylococcus epidermidis is one of the most multiple resistances to antibiotics in the recent years. Therefore, practically-prescribed antibiotics in the treatment of these strains are not effective. Plant-derived antibacterial is one of the most interesting sources of new therapeutics. The present study was to investigate antibacterial, synergy and modes of action of quercetin and amoxicillin against amoxicillin-resistant Staphylococcus epidermidis (ARSE).

Methods: The MICs, checkerboard assay, viability curves, cytoplasmic membrane (CM) permeability, enzyme assay, transmission electron microscopy, confocal microscopy and FT-IR microspectroscopy measurement was performed.

Results: The MICs of amoxicillin, penicillin, quercetin and kaempferol against all ARSE strains were 16, 200, 256-384 and $>1024 \mu \mathrm{g} / \mathrm{mL}$ respectively. Synergistic effects were exhibited on amoxicillin plus quercetin and penicillin plus kaempferol against these strains at FIC index 0.50 and $<0.38$ respectively. The synergistic activity of quercetin plus amoxicillin was confirmed by the viable count. This combination increased CM permeability, caused marked morphological, peptidoglycan and cytoplasmic membrane damage, increased protein amide I and II, but decreased fatty acid in bacterial cells. The quercetin had an inhibitory activity against $\beta$-lactamase.

Conclusions: So, these findings are the first report that quercetin has the synergistic effect with amoxicillin against ARSE via four modes of actions, inhibit peptidoglycan synthesis and $\beta$-lactamases activity, increase CM permeability and protein amide I and II but decrease fatty acid in bacterial cells. Of course, this flavonol has the dominant potential to develop a brand-new collateral phytochemical agent plus amoxicillin to treat ARSE. Future work should focus on the bioavailability, efficacy and toxicity in animal and human studies, as well as, the synergistic effect on blood and tissue should be evaluated and achieved.
\end{abstract}

Keywords: Quercetin, Kaempferol, Amoxicillin, Penicillin, Amoxicillin-resistant Staphylococcus epidermidis, Synergistic activity, Mechanism of action

\footnotetext{
* Correspondence: griang@sut.ac.th

${ }^{1}$ School of Pharmacology, Institute of Science, Suranaree University of

Technology, 111 University Avenue, Suranaree Subdistrict, Muang District,

Nakhonratchasima 30000, Thailand

Full list of author information is available at the end of the article
} 


\section{Background}

In the recent years, the incidence of multidrug resistance in pathogenic and opportunistic bacteria has been increasingly documented. These bacteria pose lifethreatening risks to the hospitalized patients and their caregivers [1]. Staphylococci are one of the most numerous resistances to many new and commonly prescribed antibiotics in the current year as a consequence of the selective pressure produced by therapeutic misuse of antibiotics and abuse [2]. Both strains of Staphylococcus aureus and Staphylococcus epidermidis have accumulated multiple resistance determinants [3]. One mode of penicillin-resistant action of bacteria is by producing $\beta$ lactamase to destroy penicillins [4]. Consequently, practically-prescribed antibiotics in the treatment of these strains are not effective. Antibacterial agents available for the treatment of S. epidermidis infection exhibit toxicity and their use are frequently associated with high cost and unwanted side-effects. Thus, searching and development of novel antibacterial compounds and new strategies that can reverse the resistance to wellestablished therapeutic agents are urgently required. Plant-derived antibacterial is one of the most interesting sources of new therapeutics. Quercetin that has been found in onions, tomatoes, and honey, showed potent antibacterial activity against a wide spectrum pathogen responsible for hospital- and community-acquired by bacterial DNA gyrase and topoisomerase IV inhibition [5]. Quercetin and kaempferol, both are classified as flavonols (Fig. 1), showed to limit cancer cell growth by inducing apoptotic cell death [6] and antibacterial activity against Escherichia coli, Pseudomonas aeruginosa, Staphylococcus aureus, and Enterococcus faecalis [7]. Kaempferol, that has been isolated from tea, broccoli, delphinium, witch-hazel, grapefruit, cabbage, kale, beans, endive, leek, tomato, strawberries, grapes, Brussels' sprouts, apples and other plant sources such as the indigo plant (Polygonum tinctorium Lour.), were effective against $H$. pylori in vivo [8]. The effect of chlorineinduced bacterial injury on spectral features was investigated by using Fourier transform infrared (FT-IR) absorbance spectroscopy [9]. Moreover, FT-IR spectroscopy was used to verify the deformation of macromolecules in the bacterial membrane, upon treatment with eugenol [10]. Also, the mode of action and bimolecular such as fatty acid, nucleic acid and protein in E. coli envelope after exposure to luteolin either alone or in combination with amoxicillin were clearly obtained using FT-IR [11]. So, these studies provide evidence that an effective tool for an early evaluation of the efficiency of the anti-bacterial effect of other used drugs can be FT-IR spectroscopy [12]. The purpose of this study was to investigate the synergistic activity and mode of action of quercetin, the flavonol, plus amoxicillin against amoxicillin-resistant $S$. epidermidis strains.

\section{Methods}

\section{Materials and bacterial strains}

This study was a cross-sectional observational study to investigate the susceptibility profile of amoxicillin on Staphylococcus epidermidis isolates. These strains were obtained during the period between January and September 2015 from clinical samples of urine, wound pus, blood, and sputum, of several infection types of 736 patients admitted to the 60 public hospitals across Thailand. The study included only one clinical isolate per patient. The bacterial species and antibacterial susceptibility testing were performed at the Department of Medical Sciences, Ministry of Public Health and the Suranaree University of Technology, Thailand respectively. The $90 \%$ failure rate for amoxicillin used for the treatment of $S$. epidermidis associated with indwelling catheters, other implanted devices, otitis, sinusitis, and pharyngeal-tonsillitis of these patients have been found. The amoxicillinresistant Staphylococcus epidermidis strains (DMST $5038,5023,5868,4248$ ) (ARSE) were assigned by the Department of Medical Sciences, Ministry of Public Health, Thailand. Staphylococcus aureus ATCC 29213 (S. aureus), used as positive control, were purchased from the American Type Culture Collection (ATCC). Quercetin (purity $98 \%$ ) and Kaempferol (purity $99 \%$ ) (Fig. 1) were purchased from the Indofine Chemical Company (New Jersey, USA). Amoxicillin, penicillin,<smiles>O=c1c(O)c(-c2ccc(O)cc2)oc2cc(O)cc(O)c12</smiles>

Fig. 1 The chemical structure of Kaempferol and Quercetin 
$\beta$-lactamase type IV, dimethyl sulfoxide (DMSO), glutaraldehyde (Grade I, $25 \%$ for EM), osmium tetroxide (4 \% for EM), Spurr Low-Viscosity Embedding Kit and nisin (from Lactococcus lactis, $2.5 \%$ balance sodium chloride and denatured milk solids) were obtained from Sigma (Sigma-Aldrich, UK). MuellerHinton agar (MHA) and Mueller-Hinton broth (MHB) was obtained from Oxoid (Basingstoke, UK).

\section{Bacterial suspension standard curves}

Bacterial suspensions standard curve method was performed to determine known viable count following the method of Richards and Xing [13] with little modifications. Briefly, the ARSE cultures were incubated in Cation-adjusted Mueller-Hinton broth (CAMHB) at $35^{\circ} \mathrm{C}$ for $20 \mathrm{~h}$. The bacterial cells were pelleted by centrifugation at $3000 \mathrm{xg}$ and were washed twice by $0.9 \% \mathrm{NaCl}$ to remove media. The cells were resuspended in sterile $0.9 \%$ $\mathrm{NaCl}$ and diluted so that 5-6 spectrophotometer readings could be obtained over the absorbance range of approximately $0.05-0.25$ at a wavelength of $500 \mathrm{~nm}$. Viable counts for each absorbance reading were determined in triplicates.

\section{Minimum inhibitory concentration (MIC) determination}

MIC determinations of amoxicillin, penicillin, nisin, quercetin and kaempferol against ARSE strains were performed following the method of Liu et al. [14]; Eumkeb et al. [11] and Clinical and Laboratory Standards Institute [15]. In brief, the inoculums of $0.25 \mathrm{~mL}$ of $5 \times 10^{6} \mathrm{CFU} / \mathrm{mL}$ bacterial suspension (20 h culture) was added to triplicate tubes containing $2.25 \mathrm{~mL}$ CAMHB plus an antibacterial or flavonols to give approximately $5 \times 10^{5} \mathrm{CFU} / \mathrm{mL}$ in each tube. The working solutions of each test agent were prepared using serial dilutions from $1024 \mu \mathrm{g} / \mathrm{mL}$ up to $1.0 \mu \mathrm{g} / \mathrm{mL}$. MIC determination was accomplished after $20 \mathrm{~h}$ of incubation at $35{ }^{\circ} \mathrm{C}$ by observing turbidity. The lowest concentrate of each agent that prevented bacterial growth was considered to be the MIC. Tubes of CAMHB without test agent were used as the control.

\section{Checkerboard determination}

Checkerboard assay to determine the synergistic activity of flavonols in combination with penicillins against penicillin-resistant $S$. epidermidis strains were executed following Eumkeb et al. [11] and Bonapace et al. [16] To sum up briefly, the $0.25 \mathrm{~mL}$ of $5 \times 10^{6} \mathrm{CFU} / \mathrm{mL}$ bacterial suspensions were added to a series of $2.25 \mathrm{~mL}$ CAMHB plus $10 \%$, serial dilution of the flavonol plus antibacterial combinations to give $5 \times 10^{5} \mathrm{CFU} / \mathrm{mL}$. Tubes of the broth without antibacterial cell were used as the control. The cultures were incubated for $20 \mathrm{~h}$ at $35{ }^{\circ} \mathrm{C}$. The tests were carried out in triplicate. MICs were determined for each antibacterial combination and the isobolograms were plotted. The interaction between the two agents was calculated by the fractional inhibitory concentration (FIC) index of the combination. The following formula was used for FIC index calculation: FIC of quercetin = MIC quercetin in combination/MIC of quercetin alone; FIC of amoxicillin = MIC of amoxicillin in the combination/MIC of amoxicillin alone; So, FIC index = FIC of quercetin + FIC of amoxicillin. When the FIC index of the combination is equal to or less than 0.5 , the combination is defined as synergistic; when FIC index falls between 0.5 and 4.0, it indicates 'no interaction' between the agents, and a value above four-term antagonism between the two compounds [17]. S. aureus ATCC 29213 was used as positive control. The MICs and FIC index is presented as the median values obtained in duplicates from three independent experiments.

\section{Determination of viability curves}

The killing curve determination was performed to confirm the synergistic activity of the combination following Richards and Xing [13]; Eumkeb et al. [11] and Clinical and Laboratory Standards Institute [15] methods with slight modifications. To summarize, after the FIC index was obtained, the MIC of each compound that gave synergism FIC index of the combination was chosen to investigate. The half-MICs value of amoxicillin and quercetin alone and the MICs of this combination that gave synergistic FIC index value were picked against $S$. epidermidis DMST 5038 (ARSE 5038) [18]. So that, the concentration of $8 \mu \mathrm{g} / \mathrm{mL}$ amoxicillin, $128 \mu \mathrm{g} / \mathrm{mL}$ quercetin, amoxicillin at $4 \mu \mathrm{g} / \mathrm{mL}$ plus quercetin at $64 \mu \mathrm{g} / \mathrm{mL}$ combinations and control (without amoxicillin or quercetin) was tested. The cultures were prepared on CAMHB for $20 \mathrm{~h}$ at $35{ }^{\circ} \mathrm{C}$. Inocula of $2 \mathrm{~mL}$ of culture were added into $98 \mathrm{~mL}$ CAMHB and shaking at 100 r.p.m. at $37^{\circ} \mathrm{C}$ for $4 \mathrm{~h}$ to give $\log$ phase. Bacterial cultures were adjusted in saline to give $5 \times 10^{6} \mathrm{CFU} / \mathrm{mL}$. Log phase of the cultures was added to CAMHB plus amoxicillin and quercetin either alone, or combined agents at concentrations mention above. The bacterial suspensions were incubated at $37^{\circ} \mathrm{C}$ in the shaker water bath. Viable counts were determined after a contact time of $0,0.5,1,2,4,6,8$ and $24 \mathrm{~h}$. Subsequent dilution plating on MHA agar plates in triplicate and incubation at $35^{\circ} \mathrm{C}$ for $20 \mathrm{~h}$ were allowed the counting of growing colonies [19].

\section{Cytoplasmic membrane permeability}

The cytoplasmic membrane permeabilization was performed as previously described by Shen et al. [20] and Zhou et al. [21] with some modifications. This method was performed by measurement the release of UVabsorbing material concentrations using UV-VIS spectrophotometer. The ARSE 5038 strain was conducted in 
this experiment. In brief, this ARSE culture was prepared on CAMHB for $20 \mathrm{~h}$ at $35^{\circ} \mathrm{C}$. Inocula of $2.0 \mathrm{~mL}$ of culture were added into $98.0 \mathrm{~mL}$ CAMHB and shaking at 100 r.p.m. at $37^{\circ} \mathrm{C}$ for $4 \mathrm{~h}$ to give log phase. Bacterial cultures were adjusted in saline to give $5 \times$ $10^{6} \mathrm{CFU} / \mathrm{mL}$. Log phase of the adjusted cultures $1.0 \mathrm{~mL}$ was added to $9.0 \mathrm{~mL}$ of $2.5 \mathrm{mmol} / \mathrm{L}$ sodium HEPES buffer $(\mathrm{pH}$ 7.0) supplemented with $100 \mathrm{mmol} / \mathrm{L}$ glucose plus $8 \mu \mathrm{g} / \mathrm{mL}$ amoxicillin, $128 \mu \mathrm{g} / \mathrm{mL}$ quercetin $(1 / 2$ $\mathrm{MIC}$ ), and $3 \mu \mathrm{g} / \mathrm{mL}$ amoxicillin plus $48 \mu \mathrm{g} / \mathrm{mL}$ quercetin $(3 / 4 \mathrm{FIC})$ in each flask to give a final concentration at $5 \times$ $10^{5} \mathrm{CFU} / \mathrm{mL}$. The flasks of cell suspension without antibacterial cell were used as the negative control and with $128 \mu \mathrm{g} / \mathrm{mL}$ nisin $(1 / 2 \mathrm{MIC})$ was used as positive control. The bacterial suspensions were incubated at $37^{\circ} \mathrm{C}$ in the shaker water bath. The CM permeability was determined after a contact time of $0,0.5,1.0,2.0,3.0$ and $4.0 \mathrm{~h}$. After treatment, samples $(1.0 \mathrm{~mL})$ were taken every contact time and filtered through a sterile nitrate cellulose membrane $(0.22 \mu \mathrm{m})$, and $\mathrm{OD}_{260}$ value of the supernatant was taken as a percentage of the extracellular UVabsorbing materials released by cells. All the measurements were done in triplicates in Varian Cary 1E UV/ VIS spectrophotometer [11].

\section{Enzyme assay}

Many isolated cultures of Staphylococcus epidermidis strains produced beta-lactamase [22]. Bacteria have produced $\beta$-lactamase enzymes that can inactivate $\beta$-lactam antibiotics by hydrolyzing the peptide bond of the $\beta$ lactam ring rendering the antibiotic ineffective [23]. Quercetin was investigated to clarify whether its had inhibitory activity against this enzyme or not by the $\beta$ lactamase assay [24]. Enzyme activities were performed following the method as previously described by Richards et al. [25]. Briefly, high performance liquid chromatography (HPLC) was used to measure the stability of benzylpenicillin to $\beta$-lactamase in the presence of an enzyme inhibitor. The quercetin and amoxicillin were pre-incubated with the enzyme at $37^{\circ} \mathrm{C}$ for 5 min before substrate addition. Reaction samples were injected at various times to Waters Bio-Sil C18 HL 90-5 s reverse phase column. Time-course assays were carried out using methanol/acetic acid (100:1) as stopping reagent. The analyzes of the remaining substrate were determined by reverse-phase HPLC using acetonitrile/ammonium acetate as a mobile phase [26].

\section{Transmission electron microscopy (TEM)}

Cellular damage of bacteria was examined using TEM. Amoxicillin and quercetin that dramatically decreased the MICs against ARSE 5038 were chosen for electron microscopy study when used singly and in combination. The subculture of this strain was prepared to examine by TEM following Eumkeb et al. [19]. Bacterial cells treated with $8 \mu \mathrm{g} / \mathrm{mL}$ amoxicillin, $128 \mu \mathrm{g} / \mathrm{mL}$, quercetin $(1 / 2 \mathrm{MIC})$ and $3 \mu \mathrm{g} / \mathrm{mL}$ amoxicillin plus $48 \mu \mathrm{g} / \mathrm{mL}$ quercetin $(3 / 4 \mathrm{FIC})$ were harvested after log phase of incubation and fixed in $2.5 \%$ glutaraldehyde in $0.1 \mathrm{M} \mathrm{PBS}$ at $4{ }^{\circ} \mathrm{C}$ for $2 \mathrm{~h}$. The cells were washed, postfixed for $2 \mathrm{~h}$ in $1 \%$ osmium tetroxide in $0.1 \mathrm{M} \mathrm{PBS}(\mathrm{pH} 7.2)$. After washing twice with PBS, the cells were dehydrated, infiltrated and embedded in Spur's resin. Ultrathin sections were cut, mounted on bare copper grids. Finally, specimens were counterstained with $2 \%(\mathrm{w} / \mathrm{v})$ uranyl acetate solution for $15 \mathrm{~min}$ and then with $0.25 \%$ (w/v) lead citrate solution for $15 \mathrm{~min}$ and examined with a TECHNAI $\mathrm{G}^{2}$ electron microscope (FEI, USA) operated at $120 \mathrm{kV}$.

\section{Immunofluorescence staining and confocal microscopy}

Disruption of peptidoglycan and DNA leakage after exposure to quercetin plus amoxicillin was carried out by the immunofluorescence and visualized under a confocal laser scanning microscope following the method of Teethaisong et al. [27]. In brief, after the FIC index was elucidated from checkerboard, the half-MICs value of quercetin or amoxicillin alone and the $3 / 4 \mathrm{FIC}$ of this combination that gave synergistic FIC indices were selected against ARSE 5038. The cell grown without an antibacterial agent was used as control [28].

\section{Fourier Transform-Infrared (FT-IR) microspectroscopy measurement \\ Chemicals, bacterial strain and growth conditions}

To evaluate the effect of quercetin either alone or in combination with amoxicillin on ARSE 5038 cells using FT-IR measurement, the previous method of Eumkeb et al. was followed [11]. Shortly, after the FIC index was obtained from checkerboard, the half-MICs value of quercetin or amoxicillin alone and the $3 / 4 \mathrm{FIC}$ of this combination that gave synergistic FIC indices were selected against ARSE 5038 to perform the FT-IR investigation. These cells were incubated at $37{ }^{\circ} \mathrm{C}$ in shaking water bath for $4 \mathrm{~h}$. The cell pellets were centrifuged at $3000 \mathrm{xg}$ for $10 \mathrm{~min}$ and washed twice with saline [11]. These cells were then washed twice with Milli-Q water. A small portion of the pellet was then deposited on Mirr IR low e-microscope slides (Kevey slide) to use as a substrate for FT-IR microscope analysis. These cells were then desiccated under vacuum about $20 \mathrm{~min}$ and stored in desiccators to form films suitable for analysis [29].

\section{Data preprocessing and analysis}

To achieve high $\mathrm{S} / \mathrm{N}$ ratios, 64 scans coadded were collected for each measurement in the wavenumber between 4000 and $400 \mathrm{~cm}^{-1}$ resolution of $6 \mathrm{~cm}^{-1}$. Spectra were recorded in reflection mode on a Bruker IR spectrometer (tensor 27) coupled to an IR microscope 
(Hyperion 2000) with 36x magnification. The OPUS 6.5 software (Bruker Optics, German) and the Unscrambler 9.7 software (Camo, Norway) was used to calculate the signal intensity of second derivatives and the band areas over the band baseline, give information about the concentration of the functional groups responsible for the corresponding band, was calculated and compared $[12,30]$.

To analyze the effect of variation in the composition and distribution of the biochemical components in bacterial cells during cell culture, the data were analyzed using PCA. All data analysis was carried out in the spectral range from $3000-2800 \mathrm{~cm}^{-1}$ and $1800-850 \mathrm{~cm}^{-1}$, which cover the mixed region of lipid, protein, polysaccharide and the "true" fingerprint region $[9,31]$.

\section{Statistical analysis}

All experiments were carried out in triplicate, and average values with a standard error of mean (Mean \pm SEM) were indicated. Significant differences between treated groups were compared using ANOVA. A $p$-value $<0.01$ of Scheffe's posthoc test, denoted the presence of a statistically significant difference.

\section{Results}

\section{MICs and checkerboard determinations}

The MICs of testing penicillin, nisin, and flavonols (quercetin and kaempferol; Fig. 1) against all S. epidermidis DMST strains are shown in Table 1. The results revealed that MICs of amoxicillin, penicillin, nisin, quercetin and kaempferol against all of these $S$. epidermidis strains were $16,200,256,256-384$, and $>1024 \mu \mathrm{g} / \mathrm{mL}$ respectively. These results provide evidence that these strains are resistant to amoxicillin and penicillin. Quercetin exhibited little inhibitory effect against these strains. The FIC indices of amoxicillin plus quercetin and penicillin plus kaempferol against all of these strains were 0.50 and $<0.38$ respectively. So, these combinations showed synergistic activity against all of these $S$. epidermidis strains as above mention (Checkerboard determination) [17, 32]. S. aureus ATCC 29213 was used as positive controls.

\section{Killing curve determinations}

The effect of amoxicillin and quercetin either alone or in combination on viable counts of ARSE 5038 is revealed in Fig. 2. The viable count of the cells treated with quercetin $128 \mu \mathrm{g} / \mathrm{mL}$ alone displayed slightly lower than amoxicillin $8 \mu \mathrm{g} / \mathrm{mL}$ alone between 2 and $8 \mathrm{~h}$. However, these cells were gradually recovered after eight throughout $24 \mathrm{~h}$. Obviously, the combination of amoxicillin at $4 \mu \mathrm{g} / \mathrm{mL}$ plus quercetin at $64 \mu \mathrm{g} / \mathrm{mL}$ dramatically decreased the cells to $1 \times 10^{3} \mathrm{CFU} / \mathrm{mL}$ after $8 \mathrm{~h}$ and maintained the cells count at this level throughout $24 \mathrm{~h}$. The synergistic activity of this combination has been confirmed by $\geq 2 \log 10 \mathrm{CFU} / \mathrm{mL}$ reduction of these treated cells compared to amoxicillin treat alone [33].

\section{Cytoplasmic membrane (CM) permeability assay}

The cytoplasmic membrane permeability was measured by UV-absorbing release materials as demonstrated in Fig. 3. After treatment ARSE 5038 cells with $8 \mu \mathrm{g} / \mathrm{mL}$ amoxicillin, $128 \mu \mathrm{g} / \mathrm{mL}$ nisin, $128 \mu \mathrm{g} / \mathrm{mL}$ quercetin and $3 \mu \mathrm{g} / \mathrm{mL}$ amoxicillin plus $48 \mu \mathrm{g} / \mathrm{mL}$, quercetin alone could induce the release of $260 \mathrm{~nm}$ absorbing material, which we interpret to be mostly DNA, RNA, and metabolites significantly higher than control and amoxicillin within 1 and $2 \mathrm{~h}$ respectively $(p<0.01)$. The absorbance values of amoxicillin plus quercetin and nisin treated groups were significantly higher than those of amoxicillin, quercetin treated alone and the negative control from $0.5 \mathrm{~h}$ and throughout $4 \mathrm{~h}(p<0.01)$. These results imply that quercetin alone and in combination with amoxicillin increased cytoplasmic membrane permeability of this strain $[20,21]$.

\section{Enzyme assay}

The capability of quercetin to inhibit the activity of $\beta$ lactamase type IV from E. cloacae is shown in Fig. 4. The result displayed that benzylpenicillin treated with quercetin was significantly higher than control starting

Table 1 MICS, FIC, and FIC index of amoxicillin, penicillin, quercetin, kaempferol against S. epidermidis

\begin{tabular}{|c|c|c|c|c|c|c|c|}
\hline \multirow[t]{2}{*}{ Strains } & \multicolumn{5}{|c|}{ MIC $(\mu \mathrm{g} / \mathrm{mL})$} & \multicolumn{2}{|c|}{$\mathrm{FIC}(\mu \mathrm{g} / \mathrm{mL})=\mathrm{FIC}$ index } \\
\hline & Amx & Pen & Nis & Que & Kae & Amx + Que & Pen + Kae \\
\hline S. epidermidis DMST 5038 & $16^{R}$ & $200^{R}$ & 256 & 256 & $>1024$ & $4+64=0.5^{5 /}$ & $64+64=<0.38^{5 /}$ \\
\hline S. epidermidis DMST 5023 & $16^{R}$ & $200^{R}$ & 256 & 256 & $>1024$ & $4+64=0.5^{S /}$ & $64+64=<0.38^{S l}$ \\
\hline S. epidermidis DMST 5868 & $16^{R}$ & $200^{R}$ & 256 & 384 & $>1024$ & $4+96=0.5^{5 /}$ & $64+64=<0.38^{S l}$ \\
\hline S. epidermidis DMST 4248 & $16^{R}$ & $200^{R}$ & 256 & 384 & $>1024$ & $4+96=0.5^{5 /}$ & $64+64=<0.38^{5 /}$ \\
\hline S. aureus ATCC $29213^{a}$ & $0.5^{\mathrm{S}}$ & $0.5^{\mathrm{s}}$ & 1 & N/D & N/D & N/D & $\mathrm{N} / \mathrm{D}$ \\
\hline
\end{tabular}

Each compound was measured three times

MIC Minimum inhibitory concentrations, FIC Fractional inhibitory concentration, Amx amoxicillin, Pen penicillin, Nis nisin, Que quercetin, Kae kaempferol

${ }^{S}=$ Susceptible; ${ }^{R}=$ resistant; ${ }^{S I}=$ Synergistic interaction; $N / D$ not determined

${ }^{a} S$. aureus ATCC 29213 was used as a positive control 


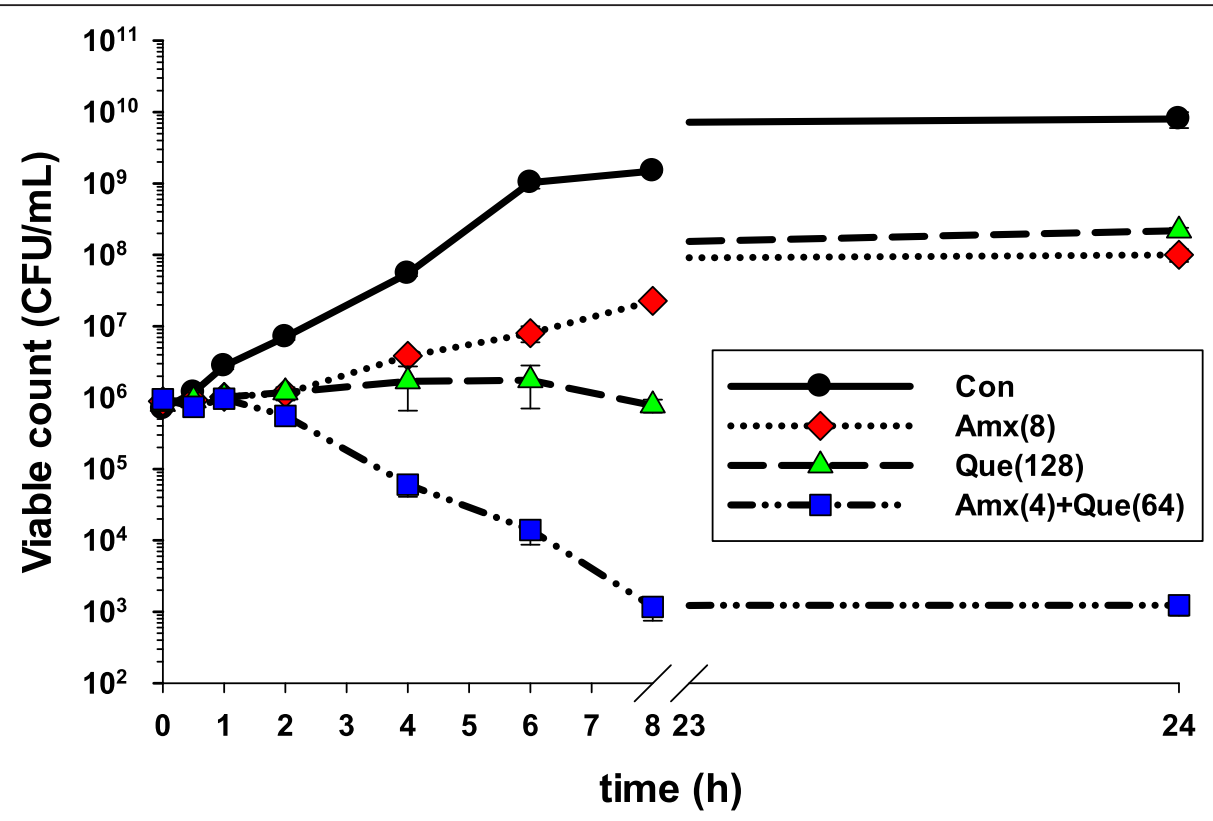

Fig. 2 The effect of amoxicillin, quercetin on the viable counts of ARSE 5038. Con=control (drugs free); Amx (8) = $8 \mu \mathrm{g} / \mathrm{mL} A m o x i c i l l i n$; Que $(128)=128 \mu \mathrm{g} / \mathrm{mL}$ Quercetin; Amx (4) + Que (64) $=4 \mu \mathrm{g} / \mathrm{mL}$ Amoxicillin plus Quercetin $64 \mu \mathrm{g} / \mathrm{mL}$. The values plotted are the means of 4 observations, and the vertical bars indicate the standard errors of the means

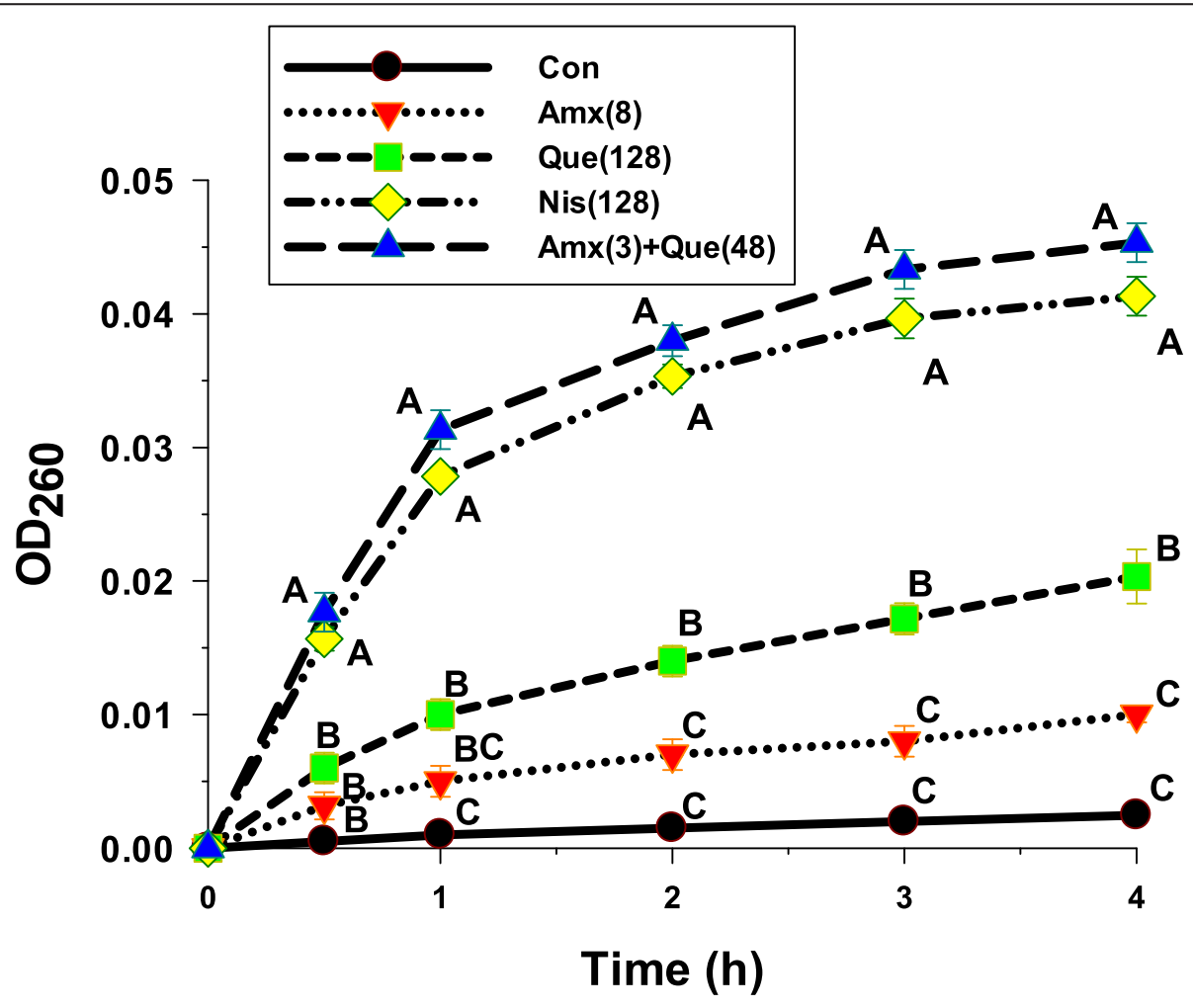

Fig. 3 The presence of $260 \mathrm{~nm}$ absorbing materials of ARSE 5038 treated with quercetin, amoxicillin. Con = control (drugs free), Amx (8)=8 $8 \mathrm{gg} / \mathrm{mL}$ Amoxicillin; Que (128) = $128 \mu \mathrm{g} / \mathrm{mL}$ Quercetin; Nis (128) = $128 \mu \mathrm{g} / \mathrm{mL}$ Nisin; Amx (3) + Que (48) = $3 \mu \mathrm{g} / \mathrm{mL}$ Amoxicillin plus $48 \mu \mathrm{g} / \mathrm{mL}$ Quercetin. Nisin at $128 \mathrm{\mu g} / \mathrm{mL}$ was used as positive control, and untreated cells were used as negative control. The mean \pm SEM for three replicates are illustrated. Means sharing the same superscript are not significantly different from each other (Scheffe's test, $p<0.01$ ) 


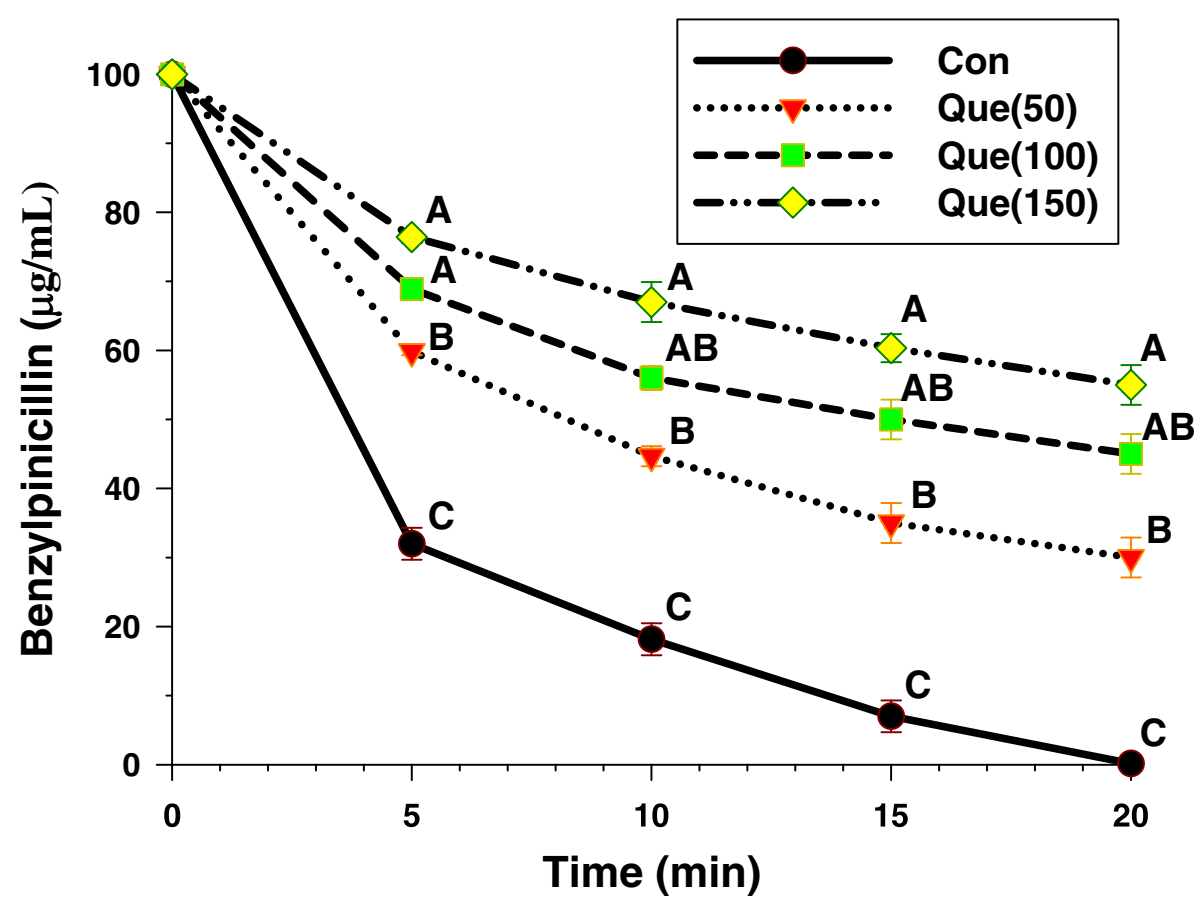

Fig. 4 The inhibitory activity of quercetin against $\beta$-lactamase in hydrolyzing benzylpenicillin. $\beta$-lactamase used from E. cloacae; Con = control (no testing agent); Que (50)= Quercetin $50 \mathrm{\mu g} / \mathrm{mL}$. The graph shows the remaining benzylpenicillin at the same time. Means sharing the same superscript are not significantly different from each other (Scheffe's test, $p<0.01$ )

from $5 \min (p<0.01)$. The benzylpenicillin remainder was significantly increased by a rise in a concentrationdependent manner. These results suggest that one activity of quercetin against ARSE may involve in $\beta$ lactamase inhibition [19].

\section{Transmission electron microscopy (TEM)}

Electron micrographs of log phase of ARSE 5038 cells in the presence of amoxicillin, quercetin either alone or in combination are shown in Fig. 5a to d. The peptidoglycan and cytoplasmic membrane can be distinguished from the control group. The morphology of the cells looked normal appearance (Fig. 5a). The ARSE cells treated with amoxicillin are revealed in Fig. 5b. This result displayed a minority of detrimental peptidoglycan and few cytoplasmic membrane hurt. The average crosssectional cell areas of these cells were bigger than control, but not a significant difference $(p<0.01)$ (Fig. 6). Whereas, the micrograph of these cells after exposure to quercetin alone is shown in Fig. 5c. The result exhibited that some of these cells revealed peptidoglycan and cytoplasmic membrane damage. The average cell areas of these cells were approximately the same as a control $(p<$ 0.01) (Fig. 6). Figure $5 \mathrm{~d}$ reveals this amoxicillin plus quercetin-treated cells. These cells demonstrated that a majority of these cells exhibited marked morphological damage, noticeable peptidoglycan and cytoplasmic membrane damage, electron transparent areas devoid of the ribosome. Obviously, these average cell areas were significantly bigger than the control $(p<0.01)$ (Fig. 6).

Immunofluorescence staining and confocal microscopy The peptidoglycan and DNA-labeled ARSE 5038 clearly showed intact coccus-shaped and no damage was observed in control cell by confocal laser scanning images (Fig. 7). These cells treated with amoxicillin and quercetin alone revealed a little damage to peptidoglycan and DNA leakage, although quercetin treated alone exhibited more peptidoglycan damage and DNA leakage than ampicillin alone. The combination of these agents caused considerable peptidoglycan damage and DNA leakage compared to controls. The merger of peptidoglycan and DNA images are also shown. These results are in substantial correspondence with TEM outcomes and support a preliminary mechanism of action of this combination is probably inhibiting peptidoglycan synthesis.

\section{FT-IR spectroscopy measurement}

The ARSE 5038 strain was grown in CAMHB medium in the presence of $8 \mu \mathrm{g} / \mathrm{mL}$ amoxicillin ( $1 / 2 \mathrm{MIC})$, $128 \mu \mathrm{g} / \mathrm{mL}$ quercetin $(1 / 2 \mathrm{MIC})$ and $3 \mu \mathrm{g} / \mathrm{mL}$ amoxicillin plus $48 \mu \mathrm{g} / \mathrm{mL}$ quercetin ( $3 / 4 \mathrm{FIC})$ and examined by FTIR microspectroscopy. The loading plots are presented in Fig. 8. The $1^{\text {st }}$ loading of amoxicillin and control groups indicate that distinct regions at $3000-2800 \mathrm{~cm}^{-1}$ ( 2962, $\sim 2923, \quad \sim 2852 \mathrm{~cm}^{-1}$ ) and $\sim 1742 \mathrm{~cm}^{-1}$ 

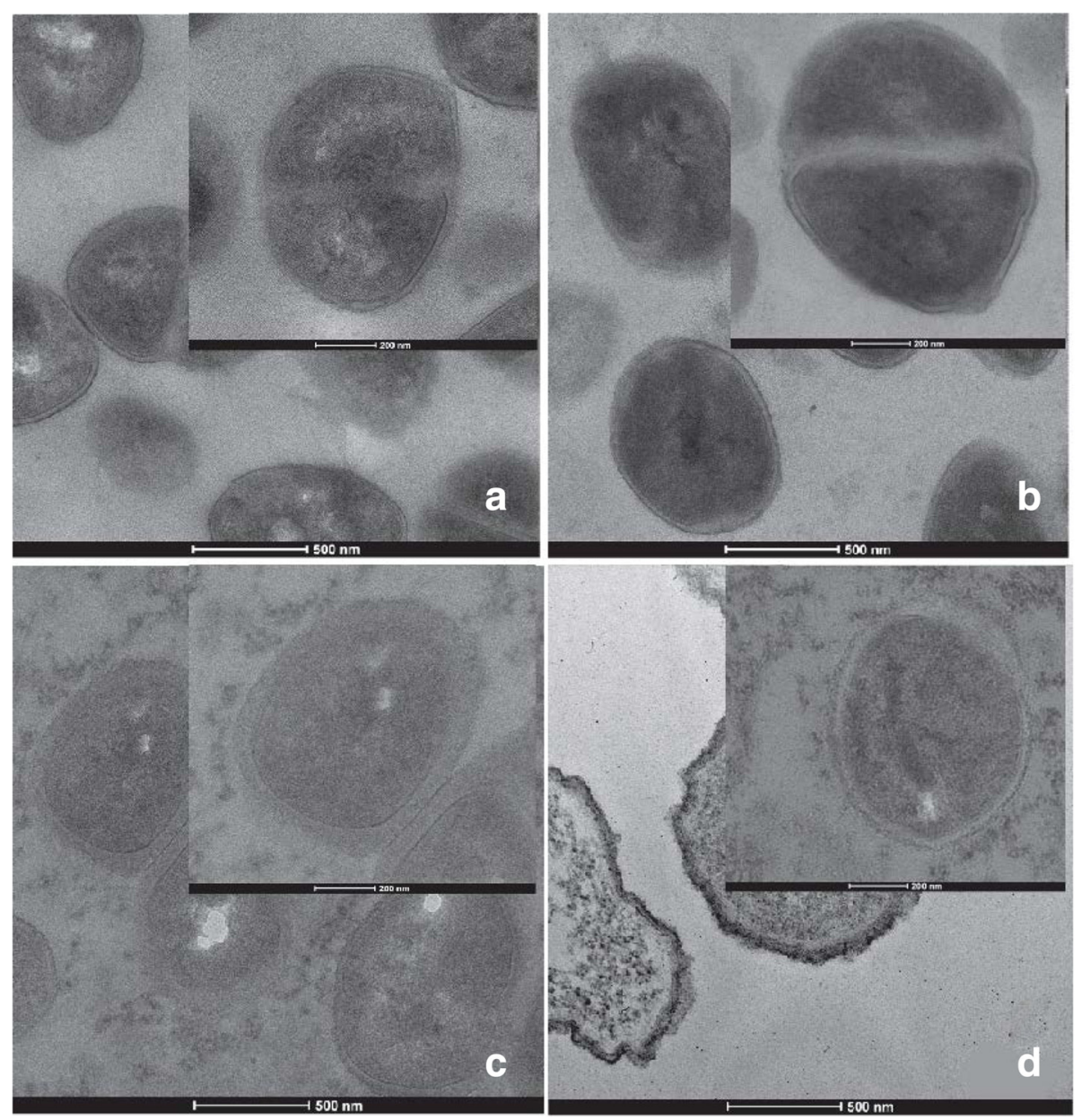

Fig. 5 Ultrathin sections of log phase ARSE 5038 grown in CAMHB containing: (a) control (drug-free); (b) Amoxicillin (8 $\mu \mathrm{g} / \mathrm{mL}$ ); (c) Quercetin $(128 \mu \mathrm{g} / \mathrm{mL}) ;(\mathbf{d})$ Amoxicillin $(3 \mathrm{\mu g} / \mathrm{mL})$ plus Quercetin $(48 \mu \mathrm{g} / \mathrm{mL})(\mathrm{a}, \mathrm{b}$, d, original magnification, 19500x; c, 17000x, bar, $500 \mathrm{~nm}$; Inset: a, b 38000x; bar, 200 nm, c, d, 34000x; bar, 200 nm)

correspond to stretching mode of $\mathrm{CH}_{2}$ and $\mathrm{CH}_{3}$ of fatty acids of the various membrane amphiphiles and ester band respectively [31]. For this reason, the signal intensity and area of the peaks of these fatty acid regions of quercetin either alone or in combination with amoxicillin clearly showed lower than those of amoxicillin and control (Fig. 9). Also, the $2^{\text {nd }}$ loading displays 3 region coefficients at $\sim 1646, \sim 1633$ and $\sim 1548 \mathrm{~cm}^{-1}$ (Fig. 8). These regions relate to average bands that are shown in Fig. 10. These cells after treatment with quercetin either alone or in combination with amoxicillin exhibited higher signal intensity and band areas at $\sim 1650, \sim 1636$ and $\sim 1549 \mathrm{~cm}^{-1}$ which are attributed to an absorption peak of secondary structure of protein amide I (alphahelix and beta-sheet) and amide II than amoxicillin and control groups [31].

The principle component analysis (PCA) can be explained by the primary source of variation in the fingerprint region to differentiate and classify bimolecular of bacterial cells after treatment with quercetin, amoxicillin either alone or in combination [34]. The 3-dimensional PCA clustering results from FT-IR spectral data of ARSE 5038 after treatment with amoxicillin, quercetin either alone or in combination is displayed in Fig. 11. The biomolecular fingerprint clusters between quercetin, amoxicillin either alone or in combination and control groups were clearly differentiated. This differentiation and classification most likely imply compositional and structural impacts of the bactericidal effect of quercetin either alone or in combination with amoxicillin on amide I components of proteins, fatty acids, polysaccharides and nucleic acids [35]. The $1^{\text {st }}$ principal component (PC1) characterizes the maximum percentage of bacterial spectral variation follow by the PC2 [36].

The loading from PC1 of ARSE 5038 cells after treatment with quercetin either alone or in combination with amoxicillin were accounted for $80 \%$ of the total variability (PC1 57 and PC2 $23 \%$ ) and case of treating group 


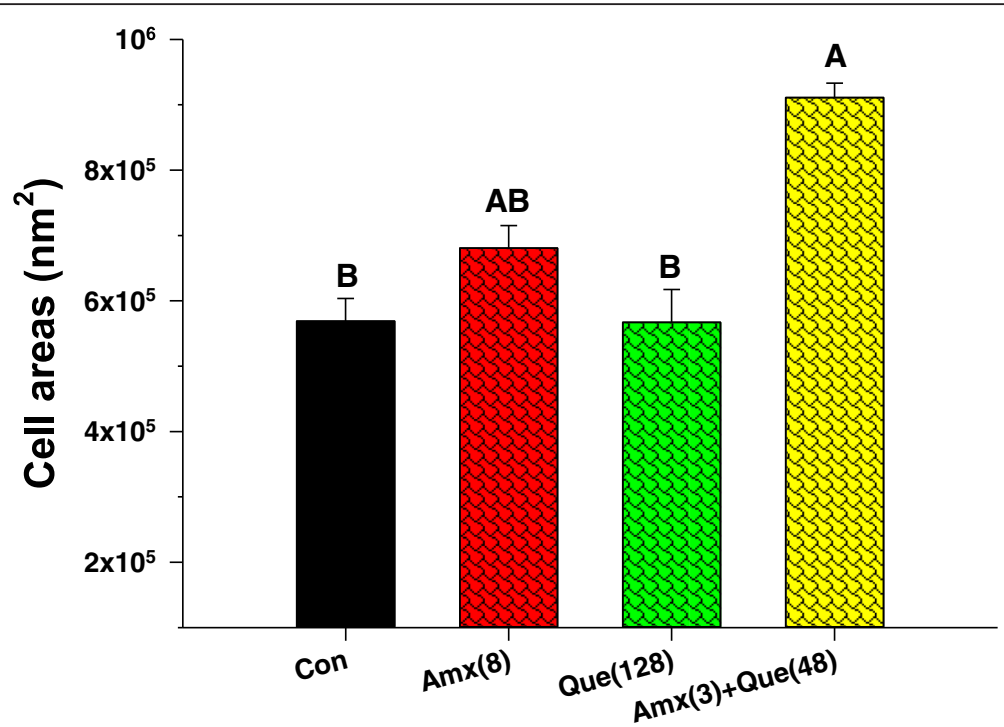

\section{Groups}

Fig. 6 The effect of amoxicillin, quercetin on an average cross-section of ARSE 5038 cell areas. Con =control (drugs free); Amx (8) = $8 \mu \mathrm{g} /$ $\mathrm{mL}$ Amoxicillin, Que (128) $=128 \mu \mathrm{g} / \mathrm{mL}$ Quercetin, Amx (3) + Que (48) $=3 \mu \mathrm{g} / \mathrm{mL}$ Amoxicillin plus $48 \mu \mathrm{g} / \mathrm{mL}$ Quercetin. The mean \pm SEM for three replicates are illustrated. Means sharing the same superscript are not significantly different from each other (Scheffe's test, $p<0.01$ )

loading PC2 was accounted for $66 \%$ of the total variability (PC2 57 and PC3 $9 \%$ ).

\section{Discussion}

Flavonoids have inhibitory activity against a variety of bacteria. The structure of flavonoids was isolated and identified. Many researchers described that flavonoids possessed antibacterial activity, including quercetin, and various quercetin glycosides [37].

The MIC results revealed that this testing S. epidermidis strains were resistant to amoxicillin and penicillin alone because of the standard value of the sensitivity of both amoxicillin and penicillin against these strains are $0.5 \mu \mathrm{g} / \mathrm{mL}[15]$. As well as quercetin, and kaempferol

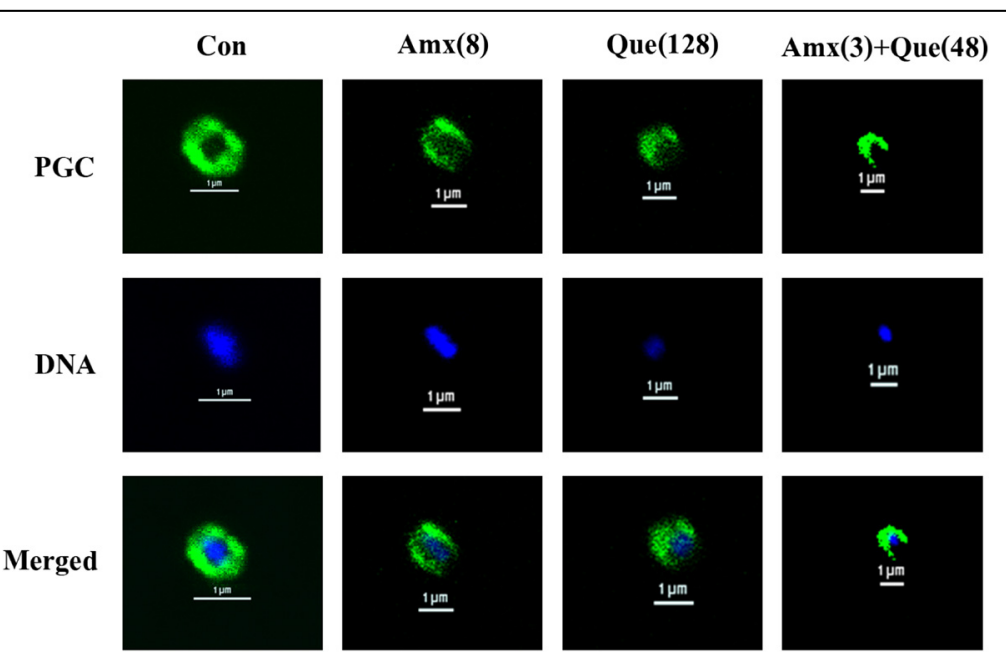

Fig. 7 Schematic representation of the results of immunofluorescence and a confocal laser scanning microscope; Samples of ARSE after treatment for $4 \mathrm{~h}$ with Amoxicillin, Quercetin, either alone or in combination. Con = control (drugs free); Amx (8) = $8 \mu \mathrm{g} / \mathrm{mL}$ Amoxicillin; Que $(128)=128 \mu \mathrm{g} / \mathrm{mL}$ Quercetin; Amx (3) + Que (48) $=3 \mu \mathrm{g} / \mathrm{mL}$ Amoxicillin plus $48 \mu \mathrm{g} / \mathrm{mL}$ Quercetin. The cells were stained for DNA with DAPI (blue) and labelled for peptidoglycan (PGC) (green) using respective antibodies. DNA in all groups was localized in the central of the cell and surrounded by a peptidoglycan layer (merged images). Scale bar $=1 \mu \mathrm{m}$ 


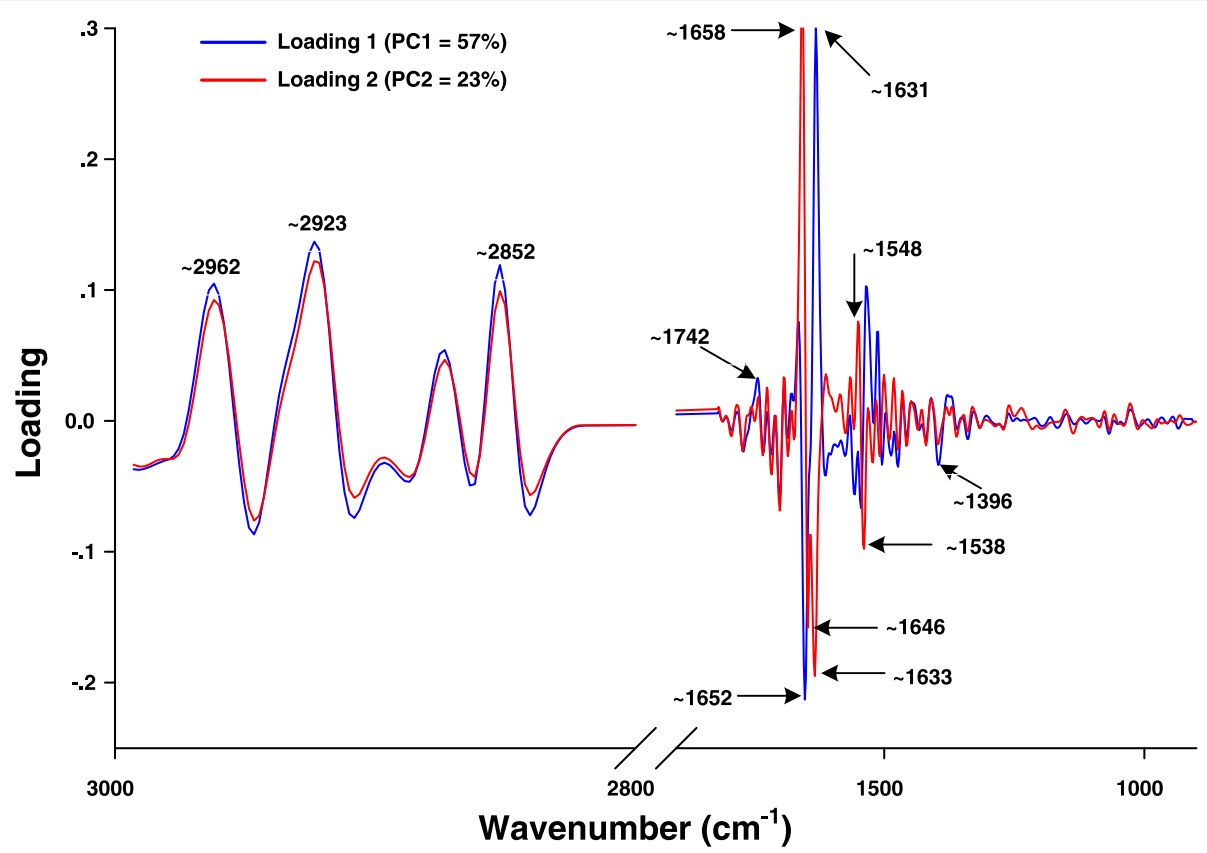

Fig. 8 The loading plot of the $1^{\text {st }}$ and $2^{\text {nd }}$ principal components from PCA of ARSE 5038. FT-IR spectra of control (drugs free), $8 \mu \mathrm{g} / \mathrm{mL}$ Amoxicillin; $128 \mathrm{\mu g} / \mathrm{mL}$ Quercetin; and $3 \mathrm{\mu g} / \mathrm{mL}$ Amoxicillin plus $48 \mathrm{\mu g} / \mathrm{mL}$ Quercetin demonstrated wavenumber at $3000-2800 \mathrm{~cm}^{-1} \mathrm{and}_{1742-1396 \mathrm{~cm}}^{-1}$

demonstrated little bacteriostatic effect against these strains. Likewise, these results are in substantial agreement with those of Hirai et al. [38] that the relatively high concentration of quercetin at $50 \mu \mathrm{M}$ showed a weak inhibitory effect against $S$. aureus and S. epidermidis at 3$9 \mathrm{~h}$ of incubation. Besides, 3-(quercetin-8-yl)-2,3-epoxyflavanone, new quercetin-derived oxidation products, at $100 \mu \mathrm{g} /$ disk showed antibacterial activity against MRSA and $H$. pylori strains at $15-16$ and $12-13 \mathrm{~mm}$ respectively and increased susceptibility of MRSA to $10 \mu \mathrm{g} / \mathrm{mL}$ oxacillin by increase inhibition zone from 1 to $18 \mathrm{~mm}$ [39]. Also, quercetin at $100-1000 \mu \mathrm{g} / \mathrm{mL}$ displayed inhibition zone 2.4-3.8 mm against S. aureus ATCC 29213 and 25923 [40]. As well as, the MICs of quercetin and amoxicillin against penicillin-resistant $S$. aureus strains were > 400 and $250 \mu \mathrm{g} / \mathrm{mL}$, respectively [19]. The checkerboard

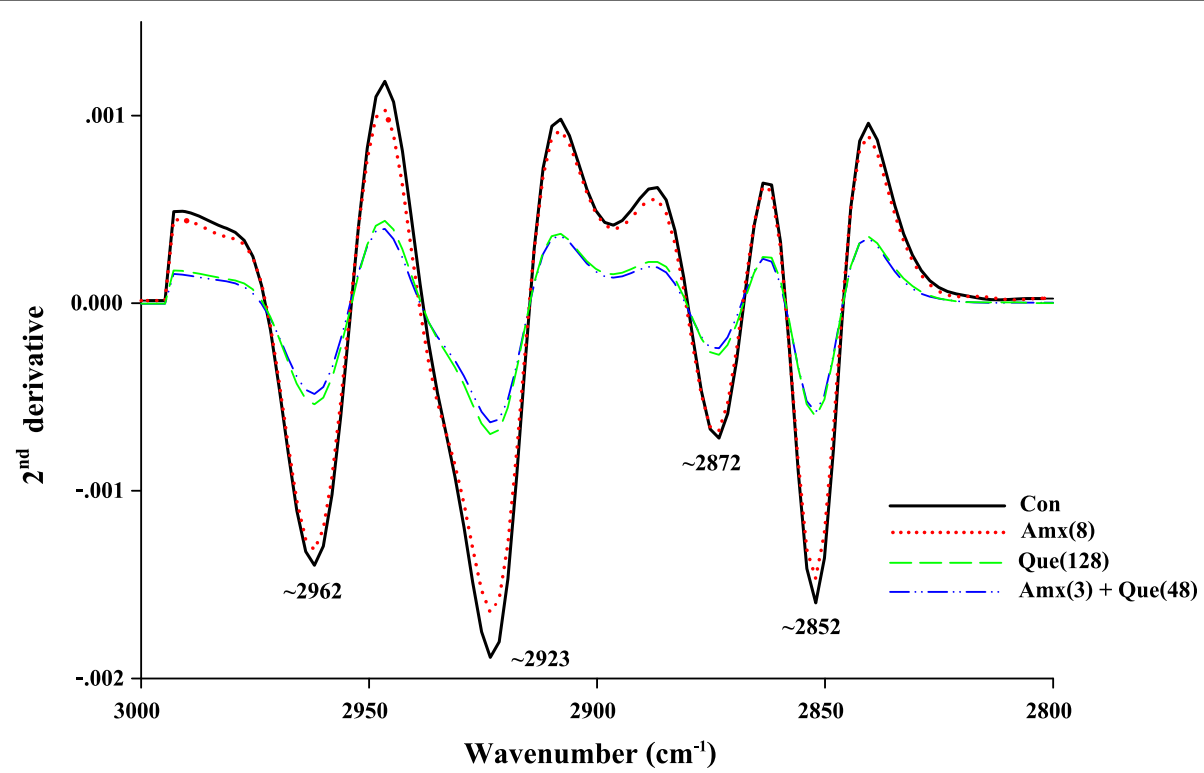

Fig. 9 Representatives $2^{\text {nd }}$ derivative transformation spectra $\left(3000-2800 \mathrm{~cm}^{-1}\right)$ of ARSE 5038 treated with Quercetin, Amoxicillin. Con = control (drugs free), Amx (8) = $8 \mu \mathrm{g} / \mathrm{mL}$ Amoxicillin; Que (128) = $128 \mu \mathrm{g} / \mathrm{mL}$ Quercetin; Amx (3) + Que (48) = $3 \mu \mathrm{g} / \mathrm{mL}$ Amoxicillin plus $48 \mu \mathrm{g} / \mathrm{mL}$ Quercetin 


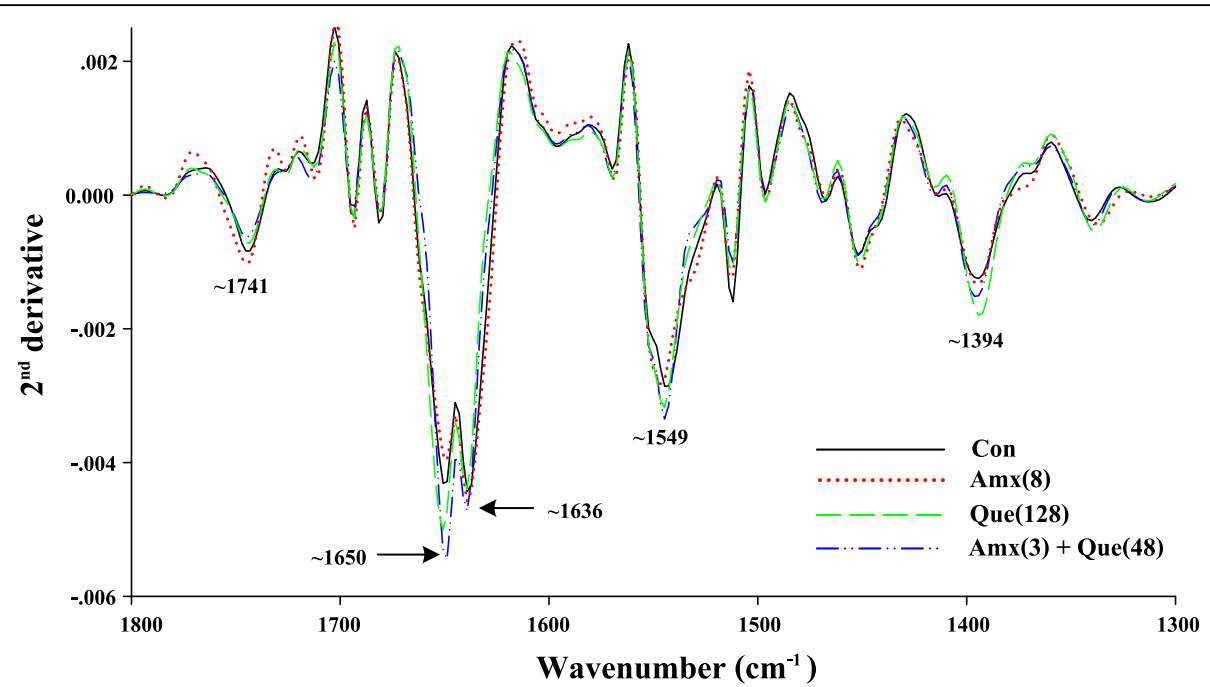

Fig. 10 Representative $2^{\text {nd }}$ derivative transformation spectra $\left(1800-1300 \mathrm{~cm}^{-1}\right)$ of ARSE 5038 treated with Quercetin, Amoxicillin. Con = control (drugs free), Amx (8) = $8 \mu \mathrm{g} / \mathrm{mL}$ Amoxicillin; Que (128) = $128 \mu \mathrm{g} / \mathrm{mL}$ Quercetin; Amx (3) + Que (48) = $3 \mu \mathrm{g} / \mathrm{mL}$ Amoxicillin plus $48 \mu \mathrm{g} / \mathrm{mL}$ Quercetin

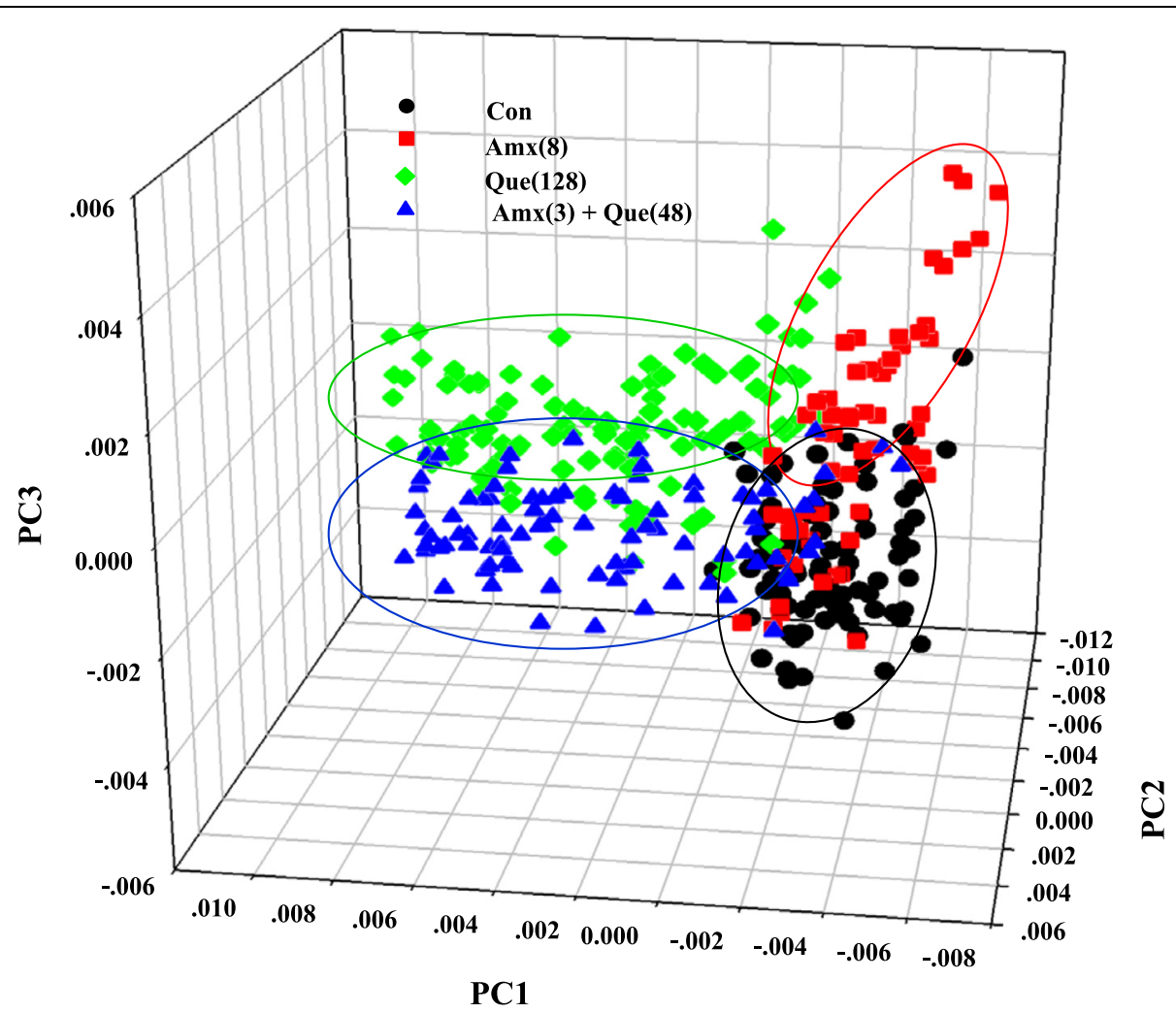

Fig. 11 PCA results constructed using spectra of ARSE 5038 treated with Quercetin, Amoxicillin. Con = control (drugs free), Amx (8) $=8 \mu \mathrm{g} / \mathrm{mL}$ Amoxicillin, Que (128) $=128 \mu \mathrm{g} / \mathrm{mL}$ Quercetin, Amx (3) + Que (48) $=3 \mu \mathrm{g} / \mathrm{mL}$ Amoxicillin plus $48 \mu \mathrm{g} / \mathrm{mL}$ Quercetin. PCA analysis (Ward's algorithm method) was constructed by using the second derivative, vector normalized spectra, over the spectral ranges from $3000-2800 \mathrm{~cm}^{-1}$ and $1750-900 \mathrm{~cm}^{-1}$ 
determination revealed synergistic effects of amoxicillin plus quercetin and penicillin plus kaempferol against all of tested S. epidermidis strains with FIC indexes at 0.50 and $<0.38$ respectively [17]. The synergy effect of amoxicillin and quercetin against ARSE 5038 has been confirmed by killing curve due to these cells have been reduced $\geq 2$ $\log 10 \mathrm{CFU} / \mathrm{mL}$ [33]. These results are in substantial correspondence with those of Eumkeb et al. that quercetin plus amoxicillin exhibited synergistic activity against penicillin-resistant $S$. aureus strains at FIC indices $<0.05$ [19]. In the same way, previous studies reported that a synergistic effect of quercetin and oxacillin against vancomycin-intermediate $S$. aureus displayed the lowest FIC index value of 0.0417 [41]. Apart from this, the antibacterial activity of quercetin plus ampicillin or vancomycin against the sensitive MRSA strain were significantly increased compared to control (no any testing agent) ( $p<$ 0.01 ) [38]. As one might expect, the quercetin and cobalt (II), cadmium (II), or mercury (II) complexes at $100 \mu \mathrm{g} /$ disc showed significant activity as bactericide against $S$. aureus at 10, 15 and $20 \mathrm{~mm}$ inhibition zone respectively, whereas sodium penicillin at $100 \mu \mathrm{g} /$ disc showed inhibition zone at $17 \mathrm{~mm}$ [42].

Naturally, the isolated Staphylococcus epidermidis strains can produce $\beta$-lactamase [22], and the result from enzyme assay found that quercetin had an inhibitory activity against $\beta$-lactamase type IV from $E$. cloacae. Hence, these results provide evidence that one mode of action of quercetin against ARSE may involve in $\beta$ lactamase inhibition and may cause the resistance of bacterial strains to its sensitivity to an antibiotic [24]. Clearly, these results seem consistent with previous findings that galangin and kaempferide, both are flavonols, showed marked inhibitory activity against penicillinase ( $\beta$-lactamase) type IV from E. cloacae [19, 24].

The $\mathrm{CM}$ permeability revealed that quercetin either alone or in combination with amoxicillin increased cytoplasmic membrane permeability of this strain. These results are in substantial agreement with previous findings that luteolin either alone or combined with amoxicillin and apigenin alone and in combination with ceftazidime increased CM permeability of amoxicillin-resistant $E$. coli and ceftazidime-resistant $E$. cloacae respectively [11, 43]. The increase in CM permeability may be one of the synergistic action of this combination against ARSE strain. This result could be explained that the formation of pores in the plasma membrane might be disrupted [21].

TEM results of amoxicillin plus quercetin-treated cells demonstrated that these cells exhibited marked morphological damage, thin peptidoglycan, and cytoplasmic membrane damage, electron transparent areas devoid of the ribosome and average cell areas significantly bigger than the control $(p<0.01)$. These results seem consistent with previous findings that the combination of ceftazidime plus galangin caused damage to the ultrastructures of the cells, affected the integrity of the cell walls and led to an increase in cell size of ceftazidime-resistant $S$. aureus [19]. Confocal microscopic images have verified the TEM results that the peptidoglycan of this combination treated cells was obviously damaged. These findings can be explained by assuming that quercetin may insert synergistic action with amoxicillin to inhibit peptidoglycan synthesis leads to marked morphological damage and delay cell division.

In general, previous findings revealed that the bactericidal effect of chlorine caused changes in the second derivative ATR spectra because of alteration in bacterial ester functional groups of lipids, structural proteins, and injured bacterial cells [9]. Our FT-IR results exhibited that ARSE 5038 cells treated with quercetin either alone or in combination with amoxicillin were decreased in fatty acid, but increased in protein amide I and amide II in bacterial cells compared to control. These results lend us to believe that quercetin alone and combined with amoxicillin may affect the content of fatty acid chains on the different membrane amphiphiles results in cytoplasmic membrane damage and an increase in cytoplasmic membrane permeabilisation. Whereas, this combination may form a complex with $\beta$-lactamase, transpeptidase, and other proteins lead to stacked- and accumulated protein in bacterial cells.

These findings provide evidence that quercetin alone has not only rather weak activity against ARSE, but also possess the ability to reverse the resistance to its first sensitivity to an antibiotic. This synergistic activity of quercetin plus amoxicillin may involve four modes of actions of this flavonol: (1) Insert action to inhibit peptidoglycan synthesis, resulting in morphological damage. (2) Inhibit $\beta$-lactamases activity. (3) Increase CM permeability and (4) decrease fatty acid, but increase protein amide I and amide II on bacterial cells. These mechanisms of actions are practically in substantial correspondence with previous findings that mode of synergistic actions of galangin, a flavonol, plus amoxicillin against ceftazidimeresistant $S$. aureus may act via three mechanisms that that inhibit protein synthesis, interact with penicillinase and cause cytoplasmic membrane damage [19].

The currently $\beta$-lactamase inhibitors could be broken by $\beta$-lactamase via a mechanism similar to the $\beta$-lactam antibiotics and could induce $\beta$-lactamase production [44]. The structure of quercetin is completely different from $\beta$-lactamase inhibitors. So, this flavonol is unlikely to induce $\beta$-lactamase production. Quercetin may be developed to combine with amoxicillin as the new combination of phytopharmaceuticals for the treatment of ARSE infection that cannot be treated with amoxicillin alone. The previous study reported that the bioavailability of quercetin in healthy individuals was relatively poor as 
evidenced by limited increases in its circulating concentrations after oral ingestion of $100 \mathrm{mg}$ quercetin glucoside [45]. Although, Murota et al. found that enzymatic aoligoglucosylation to the sugar moiety was effective for enhancing the bioavailability of quercetin glucosides in humans [46].

\section{Conclusions}

In summary, our study provides evidence that quercetin has the extraordinary potential to reverse bacterial resistance to originate traditional drug susceptibility of it. This finding is the first report of the mechanism of synergistic action of flavonol plus penicillins combination against amoxicillin-resistant $S$. epidermidis using FT-IR. Four modes of actions would be implied that this combination inhibits peptidoglycan synthesis, inhibit $\beta$ lactamases activity, increase CM permeability, and decrease fatty acid, but increase protein amide I and amide II on bacterial cells. Naturally, quercetin has restricted, limited toxicity. So, this flavonol proposes the high potential to develop a useful of novel adjunct phytopharmaceutical to amoxicillin for the treatment of ARSE. Future studies should be investigated that its bioavailability is effective to be used as antibiotics in humans. Also, the synergistic effect on blood and tissue would be evaluated and achieved.

\section{Abbreviations \\ ARSE 5038, amoxicillin-resistant Staphylococcus epidermidis DMST 5038; ARSE, amoxicillin-resistant Staphylococcus epidermidis; CAMHB, cation- adjusted Meuller-Hinton broth; CM, cytoplasmic membrane; DMSO, dimethyl sulfoxide; FIC, fraction inhibitory concentration; $\mathrm{FICl}$, fraction inhibitory concentration index; FT-IR, fourier transform-infrared; MHA, Meuller-Hinton agar; MHB, Meuller-Hinton broth; MIC, minimum inhibitory concentration; TEM, transmission electron microscopy}

\section{Acknowledgments}

The authors are grateful to Dr. Nualanong Narkkong for technical assistance of TEM technique in this study.

\section{Funding}

The authors are indebted and grateful for financial support from the Thailand Research Fund through The Royal Golden Jubilee Ph.D. Program (Grant No. PHD/0125/2554).

\section{Availability of data and materials}

The raw datasets supporting the conclusions of this article can be made available by emailing the corresponding author.

\section{Authors' contributions}

SS performed the experiments and wrote the report. YT and KT analyzed data and gave comments. BD did some experiments and wrote the draft manuscript. GE designed the project, supervised the experiments and wrote the full manuscript. All authors have read and approved the final manuscript.

\section{Competing interests}

The authors declared that they have no competing interests.

\section{Consent for publication}

Not applicable.

Ethics approval and consent to participate Not applicable.

\section{Author details}

'School of Pharmacology, Institute of Science, Suranaree University of Technology, 111 University Avenue, Suranaree Subdistrict, Muang District, Nakhonratchasima 30000, Thailand. ${ }^{2}$ Synchrotron Light Research Institute (Public Organization), Suranaree Subdistrict, Muang District, Nakhonratchasima 30000, Thailand.

Received: 27 March 2016 Accepted: 28 July 2016

Published online: 04 August 2016

\section{References}

1. Jones ME, Draghi DC, Thornsberry C, Karlowsky JA, Sahm DF, Wenzel RP. Emerging resistance among bacterial pathogens in the intensive care unit-a European and North American Surveillance study (2000-002). Ann Clin Microbiol Antimicrob. 2004;3:14.

2. Mun SH, Joung DK, Kim YS, Kang OH, Kim SB, Seo YS, et al. Synergistic antibacterial effect of curcumin against methicillin-resistant Staphylococcus aureus. Phytomedicine. 2013;20:714-8.

3. Archer GL, Climo MW. Antimicrobial susceptibility of coagulase-negative staphylococci. Antimicrob Agents Chemother. 1994;38:2231-7.

4. Tenover FC. Mechanisms of antimicrobial resistance in bacteria. Am J Med. 2006;119:S3-10

5. Hossion AM, Zamami Y, Kandahary RK, Tsuchiya T, Ogawa W, Iwado A, et al. Quercetin diacylglycoside analogues showing dual inhibition of DNA gyrase and topoisomerase IV as novel antibacterial agents. J Med Chem. 2011;54:3686-703.

6. Lupu R, Menendez JA. Pharmacological inhibitors of Fatty Acid Synthase (FASN)-catalyzed endogenous fatty acid biogenesis: a new family of anti-cancer agents? Curr Pharm Biotechnol. 2006;7:483-93.

7. Al-Saif SS, Abdel-Raouf N, El-Wazanani HA, Aref IA. Antibacterial substances from marine algae isolated from Jeddah coast of Red sea, Saudi Arabia. Saudi J Biol Sci. 2014;21:57-64.

8. Kataoka M, Hirata K, Kunikata T, Ushio S, Iwaki K, Ohashi K, et al. Antibacterial action of tryptanthrin and kaempferol, isolated from the indigo plant (Polygonum tinctorium Lour.), against Helicobacter pylori-infected Mongolian gerbils. J Gastroenterol. 2001;36:5-9.

9. Al-Qadiri HM, Al-Alami NI, Al-Holy MA, Rasco BA. Using Fourier transform infrared (FT-IR) absorbance spectroscopy and multivariate analysis to study the effect of chlorine-induced bacterial injury in water. J Agric Food Chem. 2008;56:8992-7.

10. Devi KP, Nisha SA, Sakthivel R, Pandian SK. Eugenol (an essential oil of clove) acts as an antibacterial agent against Salmonella typhi by disrupting the cellular membrane. J Ethnopharmacol. 2010;130:107-15.

11. Eumkeb G, Siriwong S, Thumanu K. Synergistic activity of luteolin and amoxicillin combination against amoxicillin-resistant Escherichia coli and mode of action. J Photochem Photobiol B. 2012;117:247-53.

12. Huleihel M, Pavlov V, Erukhimovitch V. The use of FTIR microscopy for the evaluation of anti-bacterial agents activity. J Photochem Photobiol B. 2009;96:17-23.

13. Richards RM, Xing DK. In vitro evaluation of the antimicrobial activities of selected lozenges. J Pharm Sci. 1993;82:1218-20.

14. Liu IX, Durham DG, Richards RM. Baicalin synergy with beta-lactam antibiotics against methicillin-resistant Staphylococcus aureus and other beta-lactam-resistant strains of $S$. aureus. J Pharm Pharmacol. 2000;52:361-6.

15. Clinical Laboratory Standards Institute. Methods for dilution antimicrobial susceptibility tests for bacteria that grow aerobically. In: Matthew AW, Franklin RC, William AC, Micheal ND, George ME, David WH, et al., editors. Clinical and Laboratory Standards Institute document M07-A9. Pennsylvania: Clinical and Laboratory Standards Institute; 2012. p. $16-34$.

16. Bonapace CR, Bosso JA, Friedrich LV, White RL. Comparison of methods of interpretation of checkerboard synergy testing. Diagn Microbiol Infect Dis. 2002;44:363-6.

17. Odds FC. Synergy, antagonism, and what the chequerboard puts between them. J Antimicrob Chemother. 2003;52:1.

18. Wojnicz D, Jankowski S. Effects of subinhibitory concentrations of amikacin and ciprofloxacin on the hydrophobicity and adherence to epithelial cells of uropathogenic Escherichia coli strains. Int J Antimicrob Agents. 2007;29:700-4. 
19. Eumkeb G, Sakdarat S, Siriwong S. Reversing beta-lactam antibiotic resistance of Staphylococcus aureus with galangin from Alpinia officinarum Hance and synergism with ceftazidime. Phytomedicine. 2010;18:40-5.

20. Shen L, Liu D, Li M, Jin F, Din M, Parnell LD, et al. Mechanism of action of recombinant acc-royalisin from royal jelly of Asian honeybee against grampositive bacteria. PLOS ONE. 2012;7:e47194.

21. Zhou K, Zhou W, Li P, Liu G, Zhang J, Dai Y. Mode of action of pentocin 31-1: An antilisteria bacteriocin produced by Lactobacillus pentosus from Chinese traditional ham. Food Control. 2008;19:817-22.

22. Baldwin JN, Strickland RH, Cox MF. Some properties of the beta-lactamase genes in Staphylococcus epidermidis. Appl Microbiol. 1969;18:628-30.

23. Majiduddin FK, Materon IC, Palzkill TG. Molecular analysis of beta-lactamase structure and function. Int J Med Microbiol. 2002;292:127-37.

24. Eumkeb G, Siriwong S, Phitaktim S, Rojtinnakorn N, Sakdarat S. Synergistic activity and mode of action of flavonoids isolated from smaller galangal and amoxicillin combinations against amoxicillin-resistant Escherichia coli. J Appl Microbiol. 2012;112:55-64.

25. Richards RME, Xing JZ, Gregory DW, Marshall D. Mechanism of sulphadiazine enhancement of trimethoprim activity against sulphadiazine-resistant Enterococcus faecalis. J Antimicrob Chemother. 1995;36:607-18.

26. Reading C, Farmer T. Antibiotic: assessment of antimicrobial activity and resistance. London: Academic; 1983.

27. Teethaisong $Y$, Autarkool N, Sirichaiwetchakoon K, Krubphachaya P, Kupittayanant S, Eumkeb G. Synergistic activity and mechanism of action of Stephania suberosa Forman extract and ampicillin combination against ampicillin-resistant Staphylococcus aureus. J Biomed Sci. 2014;21:90.

28. Tocheva El, Matson EG, Morris DM, Moussavi F, Leadbetter JR, Jensen GJ. Peptidoglycan remodeling and conversion of an inner membrane into an outer membrane during sporulation. Cell. 2011;146:799-812.

29. Toubas D, Essendoubi M, Adt I, Pinon JM, Manfait M, Sockalingum GD. FTIR spectroscopy in medical mycology: applications to the differentiation and typing of Candida. Anal Bioanal Chem. 2007:387:1729-37.

30. Garip S, Gozen AC, Severcan F. Use of Fourier transform infrared spectroscopy for rapid comparative analysis of Bacillus and Micrococcus isolates. Food Chem. 2009;113:1301-7.

31. Naumann D. Infrared spectroscopy in microbiology. In: Myers RA, editor. Encyclopedia of analytical chemistry. Chichester: John Wiley \& Sons; 2000. p. 102-31.

32. Chan BC, Ip M, Lau CB, Lui SL, Jolivalt C, Ganem-Elbaz C, et al. Synergistic effects of baicalein with ciprofloxacin against NorA over-expressed methicillin-resistant Staphylococcus aureus (MRSA) and inhibition of MRSA pyruvate kinase. J Ethnopharmacol. 2011;137:767-73.

33. Eliopoulos GM, Moellering RC. Antimicrobial combinations. In: Lorian VS, editor. Antibiotic in laboratory medicine. Baltimore: Williams and Wilkins; 1996. p. 330-96

34. Kim S, Reuhs BL, Mauer LJ. Use of Fourier transform infrared spectra of crude bacterial lipopolysaccharides and chemometrics for differentiation of Salmonella enterica serotypes. J Appl Microbiol. 2005;99:411-7.

35. Al-Qadiri HM, Al-Holy MA, Lin M, Alami NI, Cavinato AG, Rasco BA. Rapid detection and identification of Pseudomonas aeruginosa and Escherichia coli as pure and mixed cultures in bottled drinking water using fourier transform infrared spectroscopy and multivariate analysis. J Agric Food Chem. 2006:54:5749-54

36. Naumann D, Fijala V, Labischinski $H$. The differentiation and identification of pathogenic bacteria using FT-IR and multivariate statistical analysis. Mikrochim Acta. 1988;94:373-7.

37. Hossion AM, Otsuka N, Kandahary RK, Tsuchiya T, Ogawa W, Iwado A, et al, Design, synthesis, and biological evaluation of a novel series of quercetin diacylglucosides as potent anti-MRSA and anti-VRE agents. Bioorg Med Chem. 2010;20:5349-52.

38. Hirai I, Okuno M, Katsuma R, Arita N, Tachibana M, Yamamoto Y. Characterisation of anti-Staphylococcus aureus activity of quercetin. Int J Food Sci. 2010;45:1250-4.

39. Ramos FA, Takaishi $Y$, Shirotori $M$, Kawaguchi $Y$, Tsuchiya $K$, Shibata $H$, et al. Antibacterial and antioxidant activities of quercetin oxidation products from yellow onion (Allium cepa) skin. J Agric Food Chem. 2006:54:3551-7.

40. Vaquero MJR, Alberto MR, de Nadra MCM. Antibacterial effect of phenolic compounds from different wines. Food Control. 2007;18:93-101.

41. Basri DF, Zin NM, Bakar NS, Rahmat F, Mohtar M. Synergistic effects of phytochemicals and oxacillin on laboratory passage-derived vancomycin -intermediate Staphylococcus aureus strain. J Med Sci. 2008:8:131-6.
42. Bravo A, Anacona JR. Metal complexes of the flavonoid quercetin: antibacterial properties. Trans Met Chem. 2001;26:20-3.

43. Eumkeb G, Chukrathok S. Synergistic activity and mechanism of action of ceftazidime and apigenin combination against ceftazidime-resistant Enterobacter cloacae. Phytomedicine. 2013;20:262-9.

44. Tzouvelekis LS, Zissis NP, Gazouli M, Tzelepi E, Legakis NJ. In vitro comparative assessment of beta-lactamase inhibitors and their penicillin combinations against selected enterobacteria. Int J Antimicrob Agents. 1997;8:193-7.

45. Graefe EU, Wittig J, Mueller S, Riethling AK, Uehleke B, Drewelow B, et al. Pharmacokinetics and bioavailability of quercetin glycosides in humans. J Clin Pharmacol. 2001;41:492-9.

46. Murota K, Matsuda N, Kashino Y, Fujikura Y, Nakamura T, Kato Y, et al alpha-Oligoglucosylation of a sugar moiety enhances the bioavailability of quercetin glucosides in humans. Arch Biochem Biophys. 2010;501:91-7.

\section{Submit your next manuscript to BioMed Central and we will help you at every step:}

- We accept pre-submission inquiries

- Our selector tool helps you to find the most relevant journal

- We provide round the clock customer support

- Convenient online submission

- Thorough peer review

- Inclusion in PubMed and all major indexing services

- Maximum visibility for your research

Submit your manuscript at www.biomedcentral.com/submit
) Biomed Central 